\title{
GAMBARAN PENGETAHUAN IBU TENTANG POLA ASUH PADA ANAK BERKEBUTUHAN KHUSUS DI SLB NURUL IKHSAN
}

Betristasia P, ${ }^{1}$ Arifatul Hikmah ${ }^{2}$

Akademi Kebidanan Dharma Husada Kediri

\begin{abstract}
ABSTRAK
Anak berkebutuhan khusus adalah anak yang secara pendidikan memerlukan layanan yang spesifik yang berbeda dengan anak-anak pada umumnya. Keluarga adalah lingkungan terdekat dan utama dalam kehidupan anak berkebutuhan khusus. kemampuan hidup anak berkebutuhan khusus akan sangat ditentukan oleh peran serta dan dukungan penuh dari keluarga, sebab keluarga adalah pihak yang mengenal dan memahami berbagai aspek dalam diri seseorang dengan jauh lebih baik dari pada orang-orang yang lain. Tujuan penelitian adalah untuk mengetahui gambaran pengetahuan ibu tentang pola asuh pada anak berkebutuhan khusus.

Desain penelitian yang digunakan adalah deskriptif. Populasinya adalah semua ibu yang memiliki anak berkebutuhan khusus di SLB Nurul Ikhsan Desa Ngadiluwih Kecamatan Ngadiluwih Kabupaten Kediri. Teknik Sampling yang digunakan adalah total sampling, dengan jumlah 32 responden. Variabel yaitu pengetahuan ibu tentang pola asuh pada anak berkebutuhan khusus. Instrument yang digunakan adalah kuesioner. Data yang terkumpul diolah melalui editing, coding, scoring dan tabulating.

Hasil penelitian menunjukkan pengetahuan baik sebanyak 11 responden (34,4\%), pengetahuan cukup 12 responden $(37,5 \%)$ dan pengetahuan kurang 9 responden $(28,1 \%)$.

Karena masih kurangnya pengetahuan ibu tentang pola asuh diharapkan Dinas Pendidikan Kabupaten Kediri lebih giat lagi untuk meningkatkan penyuluhan bagi ibu mengenai pola asuh pada anak berkebutuhan khusus serta ibu lebih aktif dalam mencari informasi dari berbagai sumber misalnya media massa maupun media elektronik.
\end{abstract}

Kata kunci : Pengetahuan, ibu, Pola Asuh, Anak Berkebutuhan Khusus 


\section{PENDAHULUAN}

Tidak setiap anak mengalami perkembangan normal. Banyak di antara mereka yang dalam perkembangannya mengalami hambatan, gangguan, kelambatan, atau memiliki faktor-faktor resiko sehingga untuk mencapai perkembangan optimal diperlukan penanganan atau intervensi khusus. Kelompok inilah yang kemudian dikenal sebagai anak berkebutuhan khusus. (Suparno, 2007).

Angka anak dengan kebutuhan khusus memang belum terdata secara akurat dan spesifik. Namun secara umum, bila menarik dari asumsi PBB (Persatuan Bangsa-Bangsa atau United Nations) yang memperkirakan bahwa paling sedikit $10 \%$ anak usia sekolah menyandang kebutuhan khusus. Sebesar 30\% anak atau sekitar 40 juta anak Indonesia diperkirakan memiliki gangguan perkembangan serta memiliki kebutuhan khusus. Jumlah anak berkebutuhan khusus di Indonesia setiap tahunnya mengalami tren peningkatan.

Pada Hari Autis Sedunia bulan April 2010, diketahui bahwa prevalensi anak berkebutuhan khusus saat ini mencapai 10 anak dari 100 anak. Berdasarkan data ini menunjukkan $10 \%$ populasi anak-anak adalah anak berkebutuhan khusus dan mereka harus mendapatkan pelayanan khusus. (Wordpress, 2010). Efektivitas berbagai program penanganan dan peningkatan kemampuan hidup anak berkebutuhan khusus akan sangat ditentukan oleh peran serta dan dukungan penuh dari keluarga, sebab keluarga adalah pihak yang mengenal dan memahami berbagai aspek dalam diri seseorang dengan jauh lebih baik dari pada orang-orang yang lain. (Heward, 2003).

Upaya mengoptimalkan perkembangan anak dan remaja berkebutuhan khusus tidak lain adalah dengan memberikan pendidikan dan latihan yang dibutuhkan, baik yang terkait dengan kemampuan hidup sehari-hari, materi akademis, maupun ketrampilan kerja. Pendidikan untuk individu berkebutuhan khusus ini dikenal dengan istilah Pendidikan Luar Biasa (PLB). (Hunt dan Marshall, 2005). Dengan ketidaktahuan ibu tentang pola asuh yang tepat bagi anak berkebutuhan khusus maka dapat menyebabkan anak berkebutuhan khusus tidak mendapatkan pola asuh sesuai dengan kemampuan dan potensinya, sehingga anak berkebutuhan khusus tidak dapat berkembang dan tidak dapat hidup secara mandiri di kemudian hari, oleh karena itu maka sebaiknya orang tua lebih memperhatikan anak-anaknya selain memberi pendidikan yang tepat orang tua juga harus menerapkan pola asuh yang tepat pada anak berkebutuhan khusus.

Berdasarkan uraian dari latar belakang diatas maka penulis tertarik dan ingin mengetahui "Gambaran Pengetahuan Ibu tentang Pola Asuh Pada Anak Berkebutuhan Khusus di SLB Nurul Ikhsan Desa Ngadiluwih Kec. Ngadiluwih Kab. Kediri”. 


\section{METODE PENELITIAN}

Desain penelitian ini yang digunakan adalah deskriptif. Penelitian deskriptif bertujuan untuk mendeskripsikan (memaparkan) peristiwa-peristiwa yang terjadi pada masa kini. Deskriptif peristiwa dilakukan secara sistematik dan lebih menekankan pada data faktual dari pada penyimpulan. Fenomena disajikan secara apa adanya.

Dalam penelitian ini, peneliti hanya akan menggambarkan pengetahuan ibu tenatang pola asuh pada anak berkebutuhan khusus di SLB Nurul Ikhsan Desa Ngadiluwih Kec. Ngadiluwih Kab. Kediri. Populasi yang digunakan dalam penelitian ini adalah semua ibu yang mempunyai anak berkebutuhan khusus di SLB Nurul
Ikhsan Desa Ngadiluwih Kec. Ngadiluwih Kab. Kediri berjumlah 32. Sampel yang digunakan dalam penelitian ini adalah ibu yang mempunyai anak berkebutuhan khusus di SLB Nurul Ikhsan di Desa Ngadiluwih Kec. Ngadiluwih Kab. Kediri berjumlah 32 responden.

Cara pengambilan sampel yang digunakan dalam penelitian ini adalah total sampling. Total sampling yaitu cara pengambilan sampel dengan mengambil semua anggota populasi sampel. (Hidayat, 2012 : 83). Variabel dalam penelitian ini adalah variabel tunggal yaitu pengetahuan ibu tentang pola asuh pada anak berkebutuhan khusus.

\section{Tabel III.1 Definisi Operasional Gambaran Pengetahuan Ibu Tentang Pola Asuh Pada Anak Berkebutuhan Khusus di SLB Nurul Ikhsan Desa Ngadiluwih Kecamatan Ngadiluwih Kabupaten Kediri}

\begin{tabular}{|c|c|c|c|c|c|}
\hline Variabel & $\begin{array}{l}\text { Definisi } \\
\text { Operasional }\end{array}$ & Parameter & $\begin{array}{l}\text { Alat } \\
\text { Ukur }\end{array}$ & Skala & Kriteria \\
\hline $\begin{array}{l}\text { Pengetahuan ibu } \\
\text { tentang pola asuh } \\
\text { pada anak } \\
\text { berkebutuhan } \\
\text { khusus }\end{array}$ & $\begin{array}{l}\text { Segala sesuatu } \\
\text { yang } \\
\text { diketahui ibu } \\
\text { tentang pola } \\
\text { asuh pada } \\
\text { anak } \\
\text { berkebutuhan } \\
\text { khusus di } \\
\text { SLB Nurul } \\
\text { Ikhsan Desa } \\
\text { Ngadiluwih } \\
\text { Kecamatan } \\
\text { Ngadiluwih } \\
\text { Kabupaten } \\
\text { Kediri }\end{array}$ & $\begin{array}{l}\text { Pengetahuan ibu } \\
\text { tentang pola asuh pada } \\
\text { anak berkebutuhan } \\
\text { khusus meliputi : } \\
\text { 1. Pengertian pola } \\
\text { asuh. } \\
\text { 2. Jenis pola asuh. } \\
\text { 3. Faktor-faktor yang } \\
\text { mempengaruhi pola } \\
\text { asuh. } \\
\text { 4. Prinsip dasar } \\
\text { layanan anak } \\
\text { berkebutuhan } \\
\text { khusus }\end{array}$ & $\begin{array}{l}\mathrm{K} \\
\mathrm{U} \\
\mathrm{E} \\
\mathrm{S} \\
\mathrm{I} \\
\mathrm{O} \\
\mathrm{N} \\
\mathrm{E} \\
\mathrm{R}\end{array}$ & $\begin{array}{c}\mathrm{O} \\
\mathrm{R} \\
\mathrm{D} \\
\mathrm{I} \\
\mathrm{N} \\
\mathrm{A} \\
\mathrm{L}\end{array}$ & $\begin{array}{l}\text { Pertanyaan positif } \\
\text { Jawaban benar }=1 \\
\text { Jawaban salah }=0 \\
\text { Pertanyaan negatif } \\
\text { Jawaban benar }=0 \\
\text { Jawaban salah }=1 \\
\text { (Guttman, 2008: 78) } \\
\\
\text { Baik : } 76 \%-100 \% \\
\text { Cukup : } 56 \%-75 \% \\
\text { Kurang : }<56 \% \\
\text { (Wawan, 2010) }\end{array}$ \\
\hline
\end{tabular}

Instrument yang digunakan dalam penelitian ini adalah angket atau kuesioner. Dalam penelitian ini menggunakan kuesioner dengan menggunakan 20 item pertanyaan, angket atau kuesioner yang akan 
digunakan adalah kuesioner tertutup. Penelitian dilaksanakan di SLB

Nurul Ikhsan Desa Ngadiluwih, Kecamatan Ngadiluwih Kabupaten Kediri. Tekhnik pengolahan data dengan editing, koding, skoring, dan tabulating. Teknik analisis data dengan prosentase.

$P=\frac{x}{y} \times 100 \%$

Keterangan:

$\mathrm{P} \quad$ : Prosentase $\mathrm{x} \quad$ : Skor yang didapat

y : Skor total

Hasil prosentase dari skor yang diperoleh untuk pengolahan data setiap variabel diinterpretasikan dengan skala kualitatif sebagai berikut:

1. Baik : Hasil Prosentase 45 $76 \%-100 \%$

2. Cukup : Hasil Prosentase $56 \%-75 \%$

3. Kurang : Hasil Prosentase $<56 \%$

(Wawan dan Dewi, $2010: 18$ )

\section{DISKUSI}

1. Pengetahuan Ibu Tentang Pola Asuh Pada Anak Berkebutuhan Khusus di SLB Nurul Ikhsan Desa Ngadiluwih Kecamatan Ngadiluwih Kabupaten Kediri

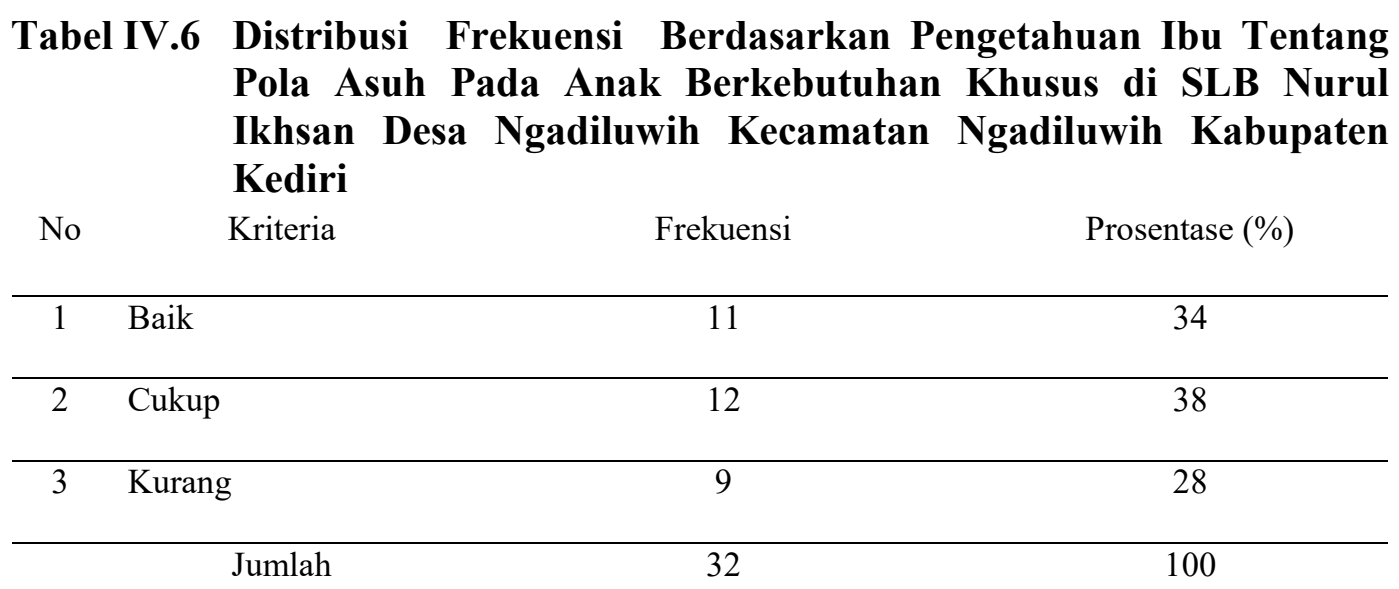

Berdasarkan tabel IV.6 diatas didapatkan dari 32 responden, sehingga dapat diketahui bahwa pengetahuan ibu tentang pola asuh pada anak berkebutuhan khusus diperoleh hasil responden terbanyak mempunyai pengetahuan cukup yaitu 12 responden $(38 \%)$. 
Pengetahuan Ibu Tentang Indikator Pola Asuh

Tabel IV.7 Distribusi Frekuensi Berdasarkan Pengetahuan Ibu Tentang Pola Asuh Anak Berkebutuhan Khusus di SLB Nurul Ikb 46 Desa Ngadiluwih Kecamatan Ngadiluwih Kabupaten Kediri

\begin{tabular}{|c|c|c|c|c|c|c|c|c|c|}
\hline \multirow{2}{*}{ No } & \multirow{2}{*}{ Pengetahuan } & \multicolumn{2}{|c|}{ Baik } & \multicolumn{2}{|c|}{ Cukup } & \multicolumn{2}{|c|}{ Kurang } & \multirow{2}{*}{$\mathrm{n}$} & \multirow{2}{*}{$\%$} \\
\hline & & $\mathrm{n}$ & $\%$ & $\mathrm{n}$ & $\%$ & $\mathrm{n}$ & $\%$ & & \\
\hline 1 & Pengertian pola asuh & 10 & 31 & 17 & 53 & 5 & 16 & 32 & 100 \\
\hline 2 & Jenis pola asuh & 13 & 41 & 14 & 44 & 5 & 16 & 32 & 100 \\
\hline 3 & Faktor-faktor & 10 & 31 & 12 & 38 & 10 & 31 & 32 & 100 \\
\hline 4 & $\begin{array}{l}\text { Prinsip dasar layanan } \\
\text { ABK }\end{array}$ & 17 & 53 & 6 & 19 & 9 & 28 & 32 & 100 \\
\hline & Jumlah & 50 & 156 & 49 & 153 & 29 & 91 & 128 & 400 \\
\hline
\end{tabular}

Berdasarkan tabel IV.7 diatas didapatkan dari 32 responden, sehingga dapat diketahui bahwa pengetahuan ibu terbanyak tentang pengertian pola asuh sebagian besar dari responden mempunyai pengetahuan cukup yaitu

1. Pengetahuan Ibu Tentang Pola Asuh Pada Anak Berkebutuhan Khusus

Dari hasil penelitian di SLB Nurul Ikhsan Desa Ngadiluwih Kec. Ngadiluwih Kab. Kediri yang dilakukan pada tanggal 1 Juli sampai dengan 3 Juli 2013 ada 32 responden dan dari hasil tersebut didapatkan ibu yang mempunyai pengetahuan cukup yaitu ada 12 responden (37,5\%), kemudian yang mempunyai pengetahuan baik ada 11 responden $(34,4 \%)$ dan yang mempunyai pengetahuan kurang ada 9 responden $(28,1 \%)$.

Pengetahuan adalah merupakan hasil dari tahu dan ini terjadi setelah orang mengadakan pengindraan terhadap suatu objek tertentu. Pengindraan terhadap objek terjadi melalui panca indra manusia yakni
17 responden (53\%) dan pengetahuan ibu tentang prinsip dasar layanan anak berkebutuhan khusus terbanyak mempunyai pengetahuan baik ada 17 responden $(53 \%)$.

penglihatan, pendengaran, penciuman, rasa dan raba dengan sendiri. Pada waktu pengindraan sampai menghasilkan pengetahuan tersebut sangat dipengaruhi oleh intensitas perhatian persepsi terhadap objek. Sebagian besar pengetahuan manusia diperoleh melalui mata dan telinga. (Notoatmodjo, 2003).Berdasarkan pada tabel penelitian yang terdapat pada tabel IV.6 dapat menunjukkan dari 30 responden yang diteliti, terdapat 18 responden $(60 \%)$ berpengetahuan baik, dan 12 responden (40\%) berpengetahuan kurang. Pada dasarnya anak berkebutuhan khusus tidak sama dengan anak normal seperti biasanya, sehingga kebutuhan merekapun tidak sama dengan anak-anak normal.

Tidak setiap anak mengalami perkembangan normal. Banyak di antara mereka yang dalam perkembangannya mengalami 
hambatan, gangguan, kelambatan, atau memiliki faktor-faktor resiko sehingga untuk mencapai perkembangan optimal diperlukan penanganan atau intervensi khusus. Kelompok inilah yang kemudian dikenal sebagai anak berkebutuhan khusus. (Suparno, 2007).

Pengetahuan ibu tentang pola asuh pada anak berkebutuhan khusus sangat penting karena dengan pengetahuan yang baik, akan menimbulkan kesadaran mereka dan akhirnya akan berperilaku sesuai dengan pengetahuan yang dimilikinya dalam hal mengasuh anak berkebutuhan khusus. Sehingga diharapkan dari pengetahuan ibu tentang pola asuh pada anak berkebutuhan khusus yang mayoritas cukup ini diharapkan dapat ditingkatkan lagi dengan cara ibu lebih aktif dalam mencari informasi dari berbagi sumber.

\section{Pengetahuan Ibu Tentang Indikator Pola Asuh Pada Anak Berkebutuhan Khusus}

\section{a. Pengetahuan Ibu Tentang Pola Asuh Pada Anak Berkebutuhan Khusus Berdasarkan Pengertian Pola Asuh}

Dari hasil penelitian menunjukkan responden di SLB Nurul Ikhsan Desa Ngadiluwih didapat 17 responden (53\%) memiliki pengetahuan cukup.

Pengetahuan adalah hasil dan tahu yang terjadi melalui proses sensoris khususnya mata dan telinga terhadap objek tertentu. Pengetahuan merupakan domain yang sangat penting untuk perbentuknya perilaku terbuka. (Sunaryo, $2004: 25$ )

Perubahan sikap dan perilaku ibu dalam memberikan pola asuh yang tepat pada anak berkebutuhan khusus tidak terjadi dikarenakan masih kurangnya pengetahuan dan pemahaman tentang pola asuh. Hal ini ditunjang dengan data bahwa sebanyak 14 responden $(43,75 \%)$ tidak pernah mendapat informasi tentang pola asuh.

Ibu tidak pernah mendapatkan informasi mengenai pola asuh pada anaknya selain dari guru di sekolah, seharusnya ibu lebih aktif mencari informasi selain dari media elektronik maupun media massa., ibu diharapkan lebih aktif mencari informasi dari sumber yang lain misalnya dari media massa, media elektronik dan dari tetangga atau teman yang lebih berpengalaman sehingga informasi yang didapat akan lebih kompleks.

Dengan semakin banyaknya informasi yang didapat, maka akan menambah pengetahuan ibu tentang pola asuh pada anak berkebutuhan khusus, sehingga ilmu tersebut dapat bermanfaat bagi kehidupan keluarga yang lebih baik.

\section{b. Pengetahuan Ibu Tentang Pola Asuh Pada Anak Berkebutuhan Khusus Berdasarkan Jenis Pola Asuh \\ Dari hasil penelitian menunjukkan} responden di SLB Nurul Ikhsan Desa Ngadiluwih didapat 14 responden (44\%) memiliki pengetahuan cukup. Pola asuh merupakan suatu sistem atau cara pendidikan, pembinaan yang diberikan orang tua/pendidik terhadap anak dalam mengasuh dan mendidiknya perlu perhatian. Pengasuh berasal dari "Asuh" artinya pemimpin, pengelola, pembimbing, maka pengasuh adalah orang yang melaksanakan tugas membimbing, 
memimpin atau mengelola. (Dinkes, 2010).

Di lingkungan sekolah anak mendapatkan pola asuh sesuai dengan potensi dan kemampuannya, pengajaran yang diberikan di sekolah diinformasikan pada orang tua, namun banyak dari orang tua yang terkadang tidak faham terhadap informasi yang diberikan oleh guru di sekolah, sehingga orang tua di rumah tidak dapat memberikan pengajaran seperti yang didapat di sekolah. Dari pengetahuan yang cukup ini dapat ditingkatkan dengan cara ibu lebih memperhatikan kebutuhan anak sesuai dengan kemampuannya dan menerapkan pola asuh yang tepat seperti yang di dapat dari guru di sekolah, serta lebih aktif mencari informasi tentang pola asuh pada anak berkebutuhan khusus melalui media massa maupun media elektronik.

\section{Pengetahuan Ibu Tentang Pola Asuh Pada Anak Berkebutuhan Khusus Berdasarkan Faktor- Faktor Yang Mempengaruhi Pola Asuh}

Dari hasil penelitian menunjukkan responden di SLB Nurul Ikhsan Desa Ngadiluwih didapat 12 responden (38\%) memiliki pengetahuan cukup. Pengetahuan atau kognitif merupakan domain yang sangat penting untuk terbentuknya tindakan seseorang (ovent behavior).

Dari pengalaman dan penelitian ternyata perilaku yang didasari oleh pengetahuan akan lebih langgeng daripada perilaku yang tidak didasari oleh pengetahuan. (Wawan dan Dewi, 2010 : 12). Pengetahuan ibu yang mayoritas cukup dikarenakan ibu tersebut tidak menerapkan pola asuh yang tepat bagi anak berkebutuhan khusus seperti halnya yang didapatkan di sekolah, ibu hanya mempercayakan seluruh proses belajar dan proses mengasuh anak pada guru di sekolah tanpa ada proses tindak lanjut di rumah. Hal ini menunjukkan bahwa ibu tidak memiliki pengalaman sendiri untuk mengasuh anaknya di rumah sesuai dengan pola asuh yang tepat bagi anak berkebutuhan khusus. Sebagian besar orang tua beranggapan bahwa kebutuhan anak sepenuhnya sudah didapatkan dari guru di sekolah. Pendidikan akan gagal tanpa partisipasi orang tua. Karena orang tua adalah orang terdekat dan yang paling mengenal dan memahami anak dalam kehidupannya sehari-hari.

Dari kurangnya pengetahuan ibu tersebut dapat lebih ditingkatkan lagi dengan cara ibu lebih aktif untuk mencari informasi dari guru di sekolah maupun pada petugas kesehatan atau tenaga kesehatan dan tempat-tempat pelayanan kesehatan terdekat yang ada di wilayah tersebut seperti puskesmas terdekat, serta menerapkan ilmu yang telah di dapatkan guna meningkatkan kemampuan, potensi serta kemandirian anak. Selain itu juga diperlukan kerja keras dari Dinas Pendidikan untuk memberikan penyuluhan lebih baik lagi dengan menggunakan media yang menarik, sehingga informasi tentang pola asuh pada anak berkebutuhan khusus dapat diterima dengan jelas dan mudah diserap.

4. Pengetahuan Ibu Tentang Pola Asuh Pada Anak Berkebutuhan Khusus Berdasarkan Prinsip Dasar Layanan Anak Berkebutuhan Khusus 
Dari hasil penelitian menunjukkan responden di SLB Nurul Ikhsan Desa Ngadiluwih didapat 17 respor $^{\text {An }}$ (53\%) memiliki pengetahuan $\mathrm{k} 49$ Sikap seseorang ditentukan oleh dua aspek yaitu aspek positif dan aspek negatif tentang suatu objek, dimana sebanyak 18 responden (56\%) pernah mendapatkan informasi mengenai pola asuh pada anak berkebutuhan khusus. Informasi yang telah didapat kemudian diterapkan dalam kehidupan sehari, hal ini sesuai dengan teori Notoatmodjo (2003) aplikasi diartikan sebagai kemampuan untuk menggunakan materi yang telah dipelajari pada situasi atau kondisi riil (sebenarnya).

Ibu yang mayoritas mempunyai pengetahuan yang baik dipengaruhi oleh berbagai informasi yang didapat. Dimana informasi diberikan oleh

\section{Simpulan}

1. Pengetahuan akseptor $\mathrm{KB}$ aktif tentang kontrasepsi implant dalam kategori baik adalah 18 responden Pengetahuan ibu tentang pengertian pola asuh adalah cukup $(53 \%)$

2. Pengetahuan ibu tentang jenis pola asuh adalah cukup (44\%)

\section{DAFTAR PUSTAKA}

\begin{tabular}{|c|c|}
\hline Arikunto, & $\begin{array}{ccc}\text { suharsimi. } & \text { 2006. } & \text { Prosedur } \\
\text { Penelitian } & \text { Suatu } & \text { Pendekatan }\end{array}$ \\
\hline & Praktik. Jakarta : Rineka Cipta \\
\hline Hidayat, & Aziz Alimul. 2012. Metode \\
\hline & Penelitian Kebidanan dan Teknik \\
\hline & Analisis Data. Jakarta : Salemba \\
\hline & Medika \\
\hline Nursalam. & 2011. Konsep dan Penerapan \\
\hline & Metodologi Penelitian Ilmu \\
\hline & Keperawatan. Jakarata : \\
\hline & Medika \\
\hline & dan Siti Pariani. 2001. Pendekatc \\
\hline & Praktis $\quad$ Metodologi \\
\hline
\end{tabular}

sumber yang terpercaya dalam hal ini adalah guru yang mengajar di sekolah maka informasi tersebut lebih mudah diserap oleh ibu, sehingga ibu mempunyai pengetahuan yang baik tentang pola asuh pada anak berkebutuhan khusus. Dari data didapat hasil penelitian terbayak ibu memiliki pekerjaan IRT dengan jumlah 17 responden $(53 \%)$.

Dengan demikian ibu dapat memberikan perhatian yang lebih banyak kepada anak-anaknya. Ibu lebih banyak waktu bersama anak-anak di rumah, sehingga ibu mengetahui kebutuhan anak dan mengetahui perkembangan anak.

3. Pengetahuan ibu tentang faktorfaktor yang mempengaruhi pola asuh adalah cukup (38\%)

4. Pengetahuan ibu tentang prinsip dasar layanan anak berkebutuhan khusus adalah baik (53\%)

Keperawatan Pengantar Statistik.Jakarta : PT. Burni Aksara Notoatmodjo, S. 2003. Ilmu Kesehatan Masyarakat. Jakarta : PT. Rineka Cipta

Sugiyono. 2008. Metode Penelitian Pendidikan. Bandung : Alfabeta

Sunaryo. 2004. Psikologi Untuk Keperawatan. Jakarta : EGC

Soemanto, Wasty. 2006. Psikologi Pendidikan. Jakarta : PT. Rineka Cipta

88 Jurnal Kebidanan Dharma Husada Vol. 4, No. 2 Oktober 2015 
Tim Penyusun Kamus Pusat Bahasa (2002). Kamus Besar Bahasa Indonesia. Jakarta : Balai Pustaka

Wawan, A. \& Dewi. 2010. Teori dan Pengukuran Pengetahuan, Sikap, dan Perilaku Manusia. Yogyakarta: Nuha Medika.

Yusuf, Syamsul. 2008. Psikologi Perkembangan Naka dan Remaja Bandung : PT. Remaja Rosdakarta Offset

Buchori, M. 2006. Pendidikan Gagal Tanpa Partisipasi Orang Tua. Jakarta : BASIS

Hunt, N and Marshall, K. 2005. Exceptional Children and Youth. Boston : Houghton Mifflin Company

Notoatmodjo, Soekidjo. 2003. Metodologi Penelitian Kesehatan. Jakarta: Rineka Cipta.

An. 2010. Anak Berkebutuhan Khusus [Internet] from : http://www.wikipedia.org/anakberke butuhankhusus

[Acessed Mei 21 $1^{\text {th }}$ 2013].

An. 2010. Bagaiman Kita Memandang Masa Depan Anak Berkebutuhan Khusus di Indonesia [Internet] from : http://cae-

indonesia.com/bagaimana-kitamemandang-masa-depan-anakberkebutuhan-khusus-di-indonesia/ [Acessed Mei 21 ${ }^{\text {th }}$ 2013].

An. 2010. Peran Orang Tua Anak Berkebutuhan Khusus [Internet] from

http://www.anakspesialhebat.com/n ews/2/Peran-Orang-Tua-Anak-

Berkebutuhan-Khusus [Acessed Mei $\underline{21}^{\text {th }}$ 2013].

Harditono, Siti Rahayu. 2006. Psikologi Perkembangan. Yogyakarta : Gadjah Mada University Press.[Internet] from http;//Ankumaro.wodrpress.com. [Acessed April 11 th2012]

Sarah, sayyida , 2011. Prinsip-prisp layanan anak. [Internet] from : http://sayyida-sarah.blogspot.com

Sindhunata. 2006. Anaka Hanyalah Beban.Jakarta : BASIS

[Intenet] from http://wordpress.com. [Acessed $\mathrm{Mei}$

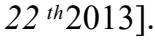

Suparno. 2007. Bahan Ajar Cetak : Pendididkan Anak Berkebutuhan Khusus. Direktorat Pendidikan Tinggi [Internet] from : Departemen Pendidikan http://wordpress.com [Acessed Mei 22 th 2013]

Lathiffah, Nurul. 2010. ABK dan Pendidikan yang Pengertian [Internet] from : http://abk-danpendidikan-yang-pengertian.htm [Acessed Mei 21 th 2013].

Tarmudji,Tarsis. 2005. Hubungan Pola Asuh Orang Tua Dengan Agresivitas Remaja. [Internet] from : http://www.depdiknas.go.id [Acessed Mei 21 th 2013]. 